\title{
THE INTERNET AS A DETERMINING FACTOR IN ECONOMIC CONVERGENCE ACROSS COUNTRIES
}

\author{
Manuel PEREZ-TRUJILLO (D) ${ }^{*}$, Marcelo LUFIN (D) 1, \\ Maricruz LACALLE-CALDERON (D) 2 \\ ${ }^{1}$ Department of Economics, Universidad Católica del Norte, Antofagasta, Chile \\ ${ }^{2}$ Department of Economic Development, Economics Faculty, Universidad Autónoma de Madrid, Spain
}

Received 04 December 2020; accepted 21 September 2021; first published online 25 November 2021

\begin{abstract}
This paper examines whether the Internet is a determining factor in explaining economic growth and convergence across countries when it acts as a channel of information and knowledge diffusion. Literature has identified around 140 possible growth factors, therefore given the contradictory results obtained from previous empirical studies it is crucial we understand the actual role of the Internet. Using the conditional convergence theory and a Bayesian panel data model averaging method from a sample of 100 countries between 1994 and 2017, our results demonstrate that an increase in access to the Internet is a non-determinant factor in economic convergence, being its probability of inclusion in the true growth model conditioned by the regressors included in the estimates and the time span analysed.
\end{abstract}

Keywords: conditional convergence, economic growth, internet, Bayesian panel data.

JEL Classification: O33, O47, C33, C39.

\section{Introduction}

The aim of this paper is to test whether the Internet as channel of information and knowledge diffusion is a determining factor in explaining economic growth and convergence across countries $^{1}$. The Internet is a significant advance in technological development that has revolutionized communication and knowledge diffusion. It has affected the global economy in various ways, enabling increases in economic productivity and commercial activity (Pélissié du Rausas et al., 2011). It has also enabled human capital, along with other institutional factors, to act as catalysts of technological catch-up, diffusion and absorption. All in all, the

\footnotetext{
${ }^{1}$ In this paper, when speaking about economic growth and convergence it should be understood in the framework of conditional convergence (see Mankiw et al., 1992).
}

${ }^{\star}$ Corresponding author. E-mail: manuel.perez@ucn.cl

Copyright $\odot 2021$ The Author(s). Published by Vilnius Gediminas Technical University

This is an Open Access article distributed under the terms of the Creative Commons Attribution License (http://creativecommons. org/licenses/by/4.0/), which permits unrestricted use, distribution, and reproduction in any medium, provided the original author and source are credited. 
Internet is a key tool of economic growth and development since it provides the basis for network externalities (Röller \& Waverman, 2001).

For the case of less developed countries, the Internet has enabled them to "tap into the global knowledge pool" (Stiglitz, 1999, p. 318). The emergence of the Internet and its growth has resulted in a democratization of knowledge, improving the price of and access to information on a global scale (OECD, 2016). This has reinforced the property of knowledge as a global public good by reducing exclusion, thus easing access to technological progress and innovation, especially in developing countries.

Although the Internet is not the only mode of information and knowledge transfer (Stanley et al., 2018), it seems to be the primary and most important ICT for diffusing information and knowledge, as it subsumes other forms of telecommunication. We will analyse the extent to which the knowledge and information revolution occurring today on the Internet affects economic growth and convergence.

Few theoretical studies have focused on how the Internet affects economic growth, and the empirical studies on this matter present contradictory results $(\mathrm{Vu}, 2019)$. Besides, the effect of the Internet, compared to that of other ICTs such as fixed landlines or mobile phones, remains somewhat ambiguous (Stanley et al., 2018). In addition to these inconclusive results, growth literature has identified around 140 growth factors, therefore it is necessary to find out whether the Internet is a determining factor in economic growth and convergence. To the best of our knowledge, there is no other empirical study on this matter.

This paper attempts to fill this gap by using both the conditional convergence theory and a Bayesian panel data model averaging approach (BPMA). The main objective and contribution of this paper is the use of the BPMA model to demonstrate whether the Internet is a determining factor in economic convergence. The rest of this paper is organized as follows. Section 1 presents a revision of the literature on the effects of ICTs and the Internet on economic growth. Section 2 describes the econometric specification, the data, and the estimation techniques. Section 3 presents our results, and the last Section offers some conclusions.

\section{Theoretical framework}

The economic growth model is based on a fundamental theoretical assumption: that knowledge is a global public good necessary for technological progress (Baumol, 1986; Stiglitz, 1999). This assumption is essential when considering the trend toward economic conditional convergence across countries (Mankiw et al., 1992 (hereafter MRW, 1992)). Under the conditional convergence assumption, countries with similar structural characteristics (technologies, rates of accumulation in reproducible factors and population growth) and similar initial conditions will converge to one another (Barro \& Sala-i-Martin, 2004). In this regard, according to the "Leader-Follower Model" (Barro \& Sala-i-Martín, 2004) if ICTs improve the access to information and knowledge in developing countries, it will also reduce the cost of imitation of such information and knowledge, and therefore increase the follower's growth rate. The conditional convergence economic growth theory has been empirically proven by several authors (MRW, 1992; Sala-i-Martin, 1995; among others). Barro \& Sala-i-Martin (2004) criticize the endogenous growth models (Romer, 1987) and affirm that "conditional 
convergence appears to be an empirical regularity" (p. 65). Under the conditional convergence assumption, since diminishing marginal returns must be taken into account in the production function for the reproducible factors, the existence of a steady-state equals 0 for those factors

Several papers have been written to study the causal link between ICTs and economic growth. Three broad and comprehensive literature surveys include Cardona et al. (2013), Vu et al. (2020) and Appiah-Otoo and Song (2021). This academic literature has clearly found ICTs are key drivers of growth in productivity and economic growth (Cardona et al., 2013; Niebel, 2018). Other papers have explored which countries (rich or poor; developing, emerging or developed) tend to gain more from the ICT revolution, but have obtained conflicting results. Some find the impact of ICTs on economic growth in emerging and developing countries is larger than in developed countries (Stanley et al., 2018; Appiah-Otoo \& Song, 2021). Other such as Dedrick et al. (2013) and Papaioannou \& Dimelis (2007) find developed countries benefit more from the ICT revolution than developing ones. Finally, Niebel (2018) does not find clear statistical results to affirm that ICTs have a larger effect on economic growth in developing or emerging countries, and therefore, he calls into question the "leapfrogging hypothesis" through ICTs.

Nevertheless, although ICTs influence the economy through a myriad of spillovers and technological complementarities, not all of them have the same impact on growth. In this regard, Stanley et al. (2018) identify the four main types of information and communication technologies (ICTs): landlines, cell phones, computer technology and the Internet. In this paper we focus on the Internet. Following the definition given by the World Bank (2018), the Internet can be used via computer, mobile phone, personal digital assistant, games machine, digital TV, etc. Therefore, since the Internet subsumes the other types of ICTs, it seems to be the primary and most important ICT for diffusing and improving access to information and knowledge. Besides, when trying to measure ICT use, Internet use is the leading ICT variable (Salahuddin \& Gow, 2016).

The emergence of the Internet has brought knowledge and innovation closer to the idea of a global public good by reducing exclusion (Stiglitz, 1999). This may be especially important for the case of developing countries who are now able to better access knowledge and information. In the words of $\mathrm{Vu}$ and Asongu (2020, p. 1), "the more distant a country is from the world's technology frontiers, the greater the potential benefits it can reap from this advantage".

However, improving access to knowledge and connecting countries through the Internet is only the beginning and arguably the easiest part. Individuals and organizations in recipient countries must have the incentives and the capabilities to use this information effectively (Madon, 2000). Incorporating external knowledge into economic activity, generally defined as absorptive capacity, is conditional on other variables that influence the rate of return on access as well as the implementation of this knowledge, such as government policies or institutions (Harris \& Yan, 2019; Barro \& Sala-i-Martín, 2004). In analysing this multifaceted concept of "absorptive capacity", Harris and Yan (2019) distinguish between "acquisition", "assimilation", and "application" of new knowledge. A country may have the capacity to access and acquire information, but this does not necessarily imply the application of such 
information. This knowledge sharing process is interactive in that it is necessary to consider the economic structure, as well as the institutions and policies for learning, not only in the countries receiving and incorporating innovations, but also in those that produce them (Lundvall et al., 2009). Furthermore, although the Internet improves access to knowledge, it is codified and not tacit. Codified knowledge can be shared through Information and Communication Technologies (ICTs) whereas tacit knowledge depends on specific social and cultural values, therefore the sharing process is also conditional on other context specific variables (Lundvall, 2017).

We focus on the Internet as the main and primary ICT for diffusing and improving access to information and knowledge. Theoretical and empirical studies have studied its impact on economic growth (Vu, 2019; Maurseth, 2018; Choi \& Yi, 2009, 2018; Bertschek et al., 2015; Salahuddin \& Gow, 2016), but with contradictory results (Vu, 2019). Fewer studies have tried to analyse whether this impact is larger among developing countries (Vu \& Asongu, 2020; Myovella et al., 2020), often obtaining the same opposing results. A possible reason for the scant empirical evidence is the lack of adequate data for conducting rigorous investigations to test this hypothesis, especially in developing countries due to the very recent advent of the Internet as a transmission channel of knowledge in those places. As a result, whether improved access to the Internet affects economic growth more in developing countries than in advanced countries is an open debate. To fill these gaps and analyse whether the Internet is a determining factor in economic growth and convergence, we use the conditional convergence growth theory to define the causality effect between the diffusion of knowledge and convergence and to empirically determine their relationship. In the following section we empirically contrast our first hypothesis (see Appendix for a theoretical explanation): The Internet is a determining factor in explaining economic convergence across countries. We also test a secondary hypothesis: The Internet has a higher effect on the economic convergence of developing economies. The second hypothesis is interesting because the developing world theoretically benefits more from the diffusion of both information and knowledge and their incorporation into its production process. Following Spar (1999), we expect this diffusion to have a greater impact on developing countries' growth, boosting their economic convergence process.

\section{Empirical analysis}

To assess the two hypotheses empirically, the literature has typically used a linear function (MRW, 1992) (see Eq. (9) in Appendix). Nevertheless, that procedure is incorrect since some elements such as population growth $\left(n_{i}\right)$ and the depreciation rate $\left(\delta_{i}\right)$ are different for each country and therefore introduce a limitation for a linear estimation of a theoretical growth equation (Dowrick \& Rogers, 2002). Therefore, we simplify our estimates following Barro $(1996,2015)$. To do so, we consider economic growth as a function of GDP per capita in the initial period $\left(\ln \left(y_{i 0}\right)\right)$, where we expect the relationship between the two to be negative and its steady state to be $\left(\ln \left(y_{i}^{*}\right)\right)$, taking:

$$
\psi_{i T-0}=\Phi\left(\ln \left(y_{i 0}\right), \ln \left(y_{i}^{*}\right)\right) \text {. }
$$


Since we use the law of motion for the countries' economic growth expressed in Eq. (7.1) in Appendix, we can define (1) as an approximation of GDP per capita in its steady state $\left(\ln \left(y_{i}^{*}\right)\right)$, taking:

$$
\psi_{i T-0}=\frac{d \ln \left(y_{i t}\right)}{d t}=\left(\ln \left(y_{i T}\right)-\ln \left(y_{i 0}\right)\right) \cdot t^{-1}=\lambda_{i} \cdot\left[\ln \left(y_{i}^{*}\right)-\ln \left(y_{i 0}\right)\right] .
$$

Hence, $\lambda_{i} \cdot \ln \left(y_{i}^{*}\right)$ can be represented as a function dependent on "an array of choice and environmental variables" (Barro, 1996, p. 9). We thus proxy the steady-state output via a set of country-specific controls including the regressors that define the term $\ln \left(y_{i}^{*}\right)$ :

$$
\lambda_{i} \cdot \ln \left(y_{i}^{*}\right) \approx \sum_{j=1}^{n} \beta_{j} \cdot x_{i t j}
$$

Including expression Eq. (3) in (1) leads to the new equation to be estimated:

$$
\psi_{i T-0}=\Phi\left(\ln \left(y_{i 0}\right), \ln \left(A_{i 0}\right), g_{i}, g_{T}, \mu \cdot D_{i T-0}, \ln \left(s_{i t}\right), \ln \left(n_{i, t}+\delta_{i, t}\right), \phi E_{i t}, J_{i t}\right),
$$

where $J_{i t}$ is a set of other controls introduced to improve consistency of the estimates (see Appendix, Table A.1 for more details on definition of the variables included in the estimates and the data sources). According to the conditional economic growth theoretical framework, the coefficient estimated for variable $\ln \left(y_{i 0}\right)$ should be negative, reflecting the convergence conditioned on the other regressors. Since we are not assuming any functional form in Eq. (4), the existing difficulties of estimating a linear growth function are simplified (Barro, 2015). The estimates of Eq. (4) introduce model uncertainty, however, due to the multiplicity of potential regressors that could explain economic growth. The corresponding empirical literature has identified a substantial number of covariates that explain economic convergence (Sala-i-Martín et al., 2004; Barro, 2015)2 , but all are not equally relevant. The goal of this paper is to identify whether the increase in Internet access as a channel of information and knowledge diffusion explains economic convergence across countries. To achieve this goal, we use a Bayesian panel data model averaging approach (BPMA), which is useful under model uncertainty, and allows us to select those regressors which have a greater probability of being included in the true model for explaining economic growth among the different regressors considered in Eq. (4) (Moral-Benito, 2012; León-González \& Montolio, 2015).

The BPMA empirical framework can be defined as follows. First, assume a well-known linear regression model:

$$
y=\theta \cdot X_{l}+\varepsilon,
$$

where $X_{l} \in\{X\}$ are the potential (unknown) regressors that should be included in the model in order to estimate $y$ properly. It is possible to find the right combination of explanatory variables $X_{l}$ by estimating all possible combinations of $X_{l}$ in (5). If $X_{l}$ contains $k$ potential variables for the estimation of Eq. (5), there will be $2^{K}$ different models $M^{l}$ (for $l=1, \ldots, 2^{K}$ ), depending on $\theta^{l}$ parameters. Each of these models considers the different hypotheses on the parameters $\theta^{l}$ and weights the potential variables contained in the matrix $X_{l}$, i.e., the potential model, constructing a weighted average over all of them that is specified in the functional form of $\Phi(\cdot)$ in (4) Sala-i-Martín (1997).

\footnotetext{
${ }^{2}$ According to Moral-Benito (2012), there are more than 140 variables identified as growth factors in the economic growth literature.
} 
The posterior distribution of the parameters $\theta^{K}$ of model $M^{K}$ is equal to the following sum of the likelihood function of $\theta^{K}$ multiplied by the posterior model probability, both conditioned by the data $(y, X)$ :

$$
P\left(\theta^{K} \mid y, X\right)=\sum_{l=1}^{2^{K}} P\left(\theta^{K} \mid M^{K}, y, X\right) \cdot P\left(M^{K} \mid y, X\right) .
$$

Meanwhile, the posterior model probability is defined as:

$$
P\left(M^{K} \mid y, X\right)=\frac{P\left(y \mid M^{K}, X\right) \cdot P\left(M^{K}\right)}{\sum_{l=1}^{2^{K}} P\left(y \mid M^{l}, X\right) \cdot P\left(M^{l}\right)} .
$$

By considering Eq. (6), we can define the point estimates of $\theta^{l}$ parameters by considering the expectations:

$$
E\left(\theta^{K} \mid y, X\right)=\sum_{l=1}^{2^{K}} P\left(M^{K} \mid y, X\right) \cdot E\left(\theta^{K} \mid M^{K}, y, X\right)
$$

$E\left(\theta^{K} \mid M^{K}, y, X\right)=\hat{\theta}^{K}$ is defined as the posterior mean of the parameters conditional on model $M^{K}$, defined as a weighted average of the posterior means of $\theta^{K}$ under each possible model. We weigh the estimates of the parameters according to their relevance to the whole set of possible models, which could define Eq. (4). Meanwhile, the posterior variance for $\theta$ is defined by:

$\operatorname{Var}\left(\theta^{K} \mid y, X\right)=\sum_{l=1}^{2^{K}} P\left(M^{K} \mid y, X\right) \cdot \operatorname{Var}\left(\theta^{K} \mid M^{K}, y, X\right)+\sum_{l=1}^{2^{K}} P\left(M^{K} \mid y, X\right) \cdot\left(\hat{\theta}^{K}-E\left(\theta^{K} \mid y, X\right)\right)^{2}$.

\subsection{Preparing the data for BPMA: solving for endogeneity and fixed effects}

For a sound estimate of Eq. (4) using the BPMA approach, we had previously to solve for two potential sources of bias: (i) fixed effects and (ii) simultaneity between the dependent variable and the regressors (Moral-Benito, 2012; León-González \& Montolio, 2015). To solve for the former, we use the forward orthogonal deviations operator instead of first applying the differences in the well-known difference-GMM model. This procedure results in the following Helmert's transformation in each variable used for the estimates $\left(z_{i t}\right)$ of Eq. (4) (Arellano \& Bover, 1995; León-González \& Montolio, 2015):

$$
\ddot{z}_{i t}=\left(\frac{T_{i}-t}{T_{i}-t+1}\right)^{\frac{1}{2}} \cdot\left[z_{i t}-\frac{1}{T_{i}-t} \cdot\left(z_{i(t+1)}+\ldots+z_{i T_{i}}\right)\right] .
$$

Equation (5) is thus defined as follows:

$$
\ddot{y}_{i t}=\theta \cdot \ddot{X}_{l, i t}+\ddot{\varepsilon}_{i t} .
$$

In Eq. (11), the later period is lost because of the transformation, so $t=1, \ldots, T_{i}-1$. Transformation Eq. (10) does not solve the simultaneity problem in our estimates, which is the second potential source of bias. We resolve this problem by guaranteeing the consistency of $\theta$. Suppose that $\ddot{X}_{l, i t}$ matrix of covariates is composed of both strictly exogenous $\left(\ddot{E}_{l, i t}\right)$ and endogenous $\left(\ddot{F}_{l, i t}\right)$ variables. Eq. (11) could then be defined as: 


$$
\ddot{y}_{i t}=\theta \cdot \ddot{E}_{l, i t}+\delta \cdot \ddot{F}_{l, i t}+\ddot{\varepsilon}_{i t},
$$

where $\operatorname{Cov}\left(\ddot{F}_{l, i t}, \ddot{\varepsilon}_{i t}\right) \neq 0$ and $E(\hat{\delta}) \neq \delta$. To improve the consistency of $\delta$, we apply a 2SLS procedure using instrumental variables (León-González \& Montolio, 2015):

$$
\ddot{F}_{l, i t}=\vartheta \cdot \ddot{Z}_{l, i t}+\ddot{v}
$$

where $\operatorname{Cov}(\ddot{\varepsilon}, \ddot{v})=0$. In Eq. (12), since $\ddot{Z}_{l, i t}$ are strictly exogenous variables, the Helmert's transformation is applied using like instruments and the differences and lags of $\ddot{F}_{l, i t}$, as in the matrix proposed by Blundell \& Bond (1998) for the system GMM estimator. Then:

where:

$$
\ddot{Z}_{l, i t}=\left[\begin{array}{ccccc}
\ddot{A}_{l, i t} & 0 & 0 & & 0 \\
0 & \Delta \ddot{F}_{l, i 2} & 0 & \ldots & 0 \\
0 & 0 & \Delta \ddot{F}_{l, i 3} & & 0 \\
\vdots & \vdots & \vdots & & \ddots
\end{array}\right] \text {, }
$$

$$
\ddot{A}_{l, i t}=\left[\begin{array}{cccc}
0 & 0 & & 0 \\
\ddot{F}_{l, i 1} & 0 & \ldots & 0 \\
0 & \ddot{F}_{l, i 2} & & 0 \\
\vdots & \vdots & & \ddots
\end{array}\right] .
$$

The 2SLS Eq. (13) will be estimated before the BPMA approach to solve the endogeneity problems of (4). To ensure comparability, we also apply a conventional system-GMM model (Arellano \& Bover, 1995; Blundell \& Bond, 1998) $)^{3}$.

\subsection{Data}

To estimate Eq. (4), we create an unbalanced panel data set of 100 countries (see list in Appendix, Table A.2) for the period 1994-2017. To test the positive theoretical relationship between improvement in access to information and knowledge through the Internet and economic convergence (see equation (10) in Appendix), we measure Internet by the number of internet users per 100 people, from ITU (2018) via World Development Indicators (World Bank, 2018). Given our research objective, we also include a distinction between OECD and non-OECD countries to test the relationship between factors across countries at different stages of development. To reduce the effect of serial correlation, we also split our sample into three-year periods: 1994-1996, 1997-1999, 2000-2002, 2003-2005, 2006-2008, 2009-2011, 2012-2014, and 2015-2017 (Barro, 2015).

\footnotetext{
${ }^{3}$ Recent studies, such as Moral-Benito et al. (2019) and Kraay (2015), provide evidence that the data do not fulfil the mean stationarity assumption (something that tends to happen when the variables have some persistence in their time series). This means that even the system-GMM model proposed leads to the use of invalid and/or weak instruments, making it preferable to use the Maximum Likelihood Estimator of Structural Equation Models method (Moral-Benito et al., 2019). This methodology is shown to be more efficient than GMM when the model fulfils the assumption of normality and suffers less from finite sample bias.
} 
Although one could think of many ways to measure the impact of the Internet ${ }^{4}$ on growth and convergence, the number of internet users per 100 people is one of the two most widely used in the empirical literature (Vu, 2019; Haini, 2019; Maurseth, 2018; Choi \& Yi, 2018, 2009; Andrés et al., 2010; Oyelaran-Oyeyinka \& Lal, 2005) ${ }^{5}$. Further, most of the other indicators are not available for most countries in our sample. In line with Oyelaran-Oyeyinka and Lal (2005), this measure of the Internet is an accepted proxy for measuring the level of Internet diffusion in developed countries. In the case of developing countries, however, not everyone has access to the Internet at home. Rather, many access via at a common service provider. The number of Internet hosts (IHs) might thus be a more relevant variable to measure a country's Internet diffusion ${ }^{6}$. Unfortunately, we lack data on IHs for the countries in our sample. Further, since the number of Internet users measures the number of individuals per 100 people who have used the Internet from any location in the last 3 months (Internet can be used by accessing it via computer, mobile phone, etc.) (World Bank, 2018), the number of Internet users and the number of IHs are highly and positively correlated.

Finally, we believe this measure is a good proxy for the impact of the Internet on economic growth. We depart from the economic assumption that average Internet use will be similar in different countries once a population has access to it. All countries will have a portion of people using the Internet for local traffic, to read the news, or to search for information and business. Even if the average use of the Internet is more or less equal in all countries, the quality or level of information sought may not be. The Internet is the tool that facilitates access to knowledge and information, but it is the use of this tool that matters for economic growth (Cortright, 2001). The capacity to absorb an improvement in access to information and knowledge differs in each country. It depends on a set of different factors, such as the level of human capital, a higher rate of trade openness, higher investment rates and/or better institutional quality (Stanley et al., 2018; Harris \& Yan, 2019; Li \& Shiu, 2012; Romer, 2006; Dasgupta et al., 2005; Caselli \& Coleman, 2001). Some countries may thus have the capacity to access and acquire information through the Internet but not the intangible assets and/or tacit knowledge needed to apply such information (Harris \& Yan, 2019). Improvement in access to information and knowledge itself may not be what is producing economic growth, but it would be when combined with the other previous factors.

For all these reasons, we decided to work with the number of Internet users per 100 people as our proxy for the diffusion of information and knowledge in an economy. These data are widely available for most countries in our sample beginning in the 1990's, something not possible with any other proxy. The variable of interest $D_{i T-0}$ is defined as the difference between the third and the first year in each period. Thus, we define $D_{i T-0}$ as the variation,

\footnotetext{
${ }^{4}$ For example, connectivity, connectivity infrastructure, host count, number of web sites, language distribution and sophistication of use.

${ }^{5}$ We could use "Fixed broadband subscriptions (per 100 people)", also from ITU. However, this proxy refers only to fixed subscriptions to high-speed access to public Internet, and its availability is lower than the proxy we are using.

${ }^{6}$ Also, although the proxy we use is a precise measure of access, it measures penetration rate (share of households in each country with access to telecommunications). A compilation of the statistics for subscriptions and use as well as access would be preferable, but these data points are not available.
} 
that is, the increase, in the number of individuals per 100 people who have used the Internet from any location in the last 3 months in every country during the three-year periods in the analysis.

Additionally, the estimates of Eq. (4) include 24 additional regressors (see Table A.2 in Appendix). Four are traditionally defined to explain economic growth theoretically, and are the following: lag of GDP per capita in logs $\left(\ln \left(y_{i 0}\right)\right)$, share of gross capital formation at current PPPs in logs $\left(\ln \left(s_{i t}\right)\right)$, logarithm for the sum of population growth and depreciation rate $\left(\ln \left(1+n_{i, t}+\delta_{i, t}\right)\right)$, and a human capital index $\left(h_{i t}=\phi E_{i t}\right)$ based on years of schooling $\left(E_{i t}\right)$ and returns to education $(\phi)$. In addition, to test our hypotheses, we also include the increase in the number of Internet' users per 100 people $\left(D_{i T-0}\right)$,

The other 19 regressors, identified in the literature as the main drivers of economic growth (Barro, 2015; Moral-Benito, 2012; Sala-i-Martín et al., 2004; Benoit, 1978) ${ }^{7}$, can be classified into the following three categories:

- Socio-economic and external environment: Share of government consumption at current PPPs $\left(P u b_{-} C_{i t}\right)$; Life expectancy in $\operatorname{logs}\left(\ln \left(\right.\right.$ Life_expect $\left.\left._{i t}\right)\right)$; Openness rate (Opennes ${ }_{i t}$ ); a time dummy $\left(\right.$ Crisis $_{i}$ ), which takes the value 1 if 2008 (i.e., beginning of the global financial crisis) and 0 otherwise; annual growth rate of prices in the economy as a whole, or Inflation ( Inflat ${ }_{i t}$ ); Total expenditure on the armed forces as a percentage of GDP $\left(M i l_{-} \exp _{i t}\right)$; People per square kilometer of land area (Pop_dens ); difference between the value of production for a stock of minerals at world prices and their total production cost as a percentage of GDP (mineral rents) (Miner_rents ); People living in urban areas $\left(\operatorname{Urban}_{i t}\right)$; labour force rate (Labor force $\left._{i t}\right)$; fertility rate $\left(\right.$ Fertility $\left._{i t}\right)$; and research and development expenditure as a percentage of GDP $\left(R \& D_{i t}\right)$.

- Governance and institutions: Democracy index $\left(\right.$ Democracy $\left._{i t}\right)$ and this index squared $\left(\right.$ Democracy $_{i t}^{2}$ ); a legal origin dummy (Legal_english $h_{i}$ ), which takes the value 1 if the country's legal origin is English and 0 otherwise; a religion dummy $\left(\right.$ Muslim $\left._{i}\right)$, which takes the value 1 if the major religion in the country is Islam and 0 otherwise.

- Geography and fixed factors: a dummy indicating if the country belongs to the OECD $\left(O E C D_{i}\right)^{8}$; a dummy identifying if the country belongs to the Latin American region $\left(\right.$ Latin $\left._{i}\right)$; a dummy identifying if the country has no direct access to a coastline (Landlocked ${ }_{i}$ ).

Because our sample is made up of seven three-year periods, we average all variables with temporal variation to create each observation.

\section{Results}

We first perform a system-GMM Panel Data analysis (see Blundell \& Bond, 1998). Table 1 presents these outcomes for the whole sample of 100 countries and includes both OECD and non-OECD countries. The division between OECD and non-OECD enables us to test

\footnotetext{
${ }^{7}$ Although more than 140 variables have been identified in the literature to explain economic growth, many are not available for our sample of countries over the entire sample period under consideration in this paper.

${ }^{8}$ See Appendix, Table A.2 for the classification of OECD countries.
} 
whether increase in number of Internet users per 100 people has greater impact on economic convergence for the developing group, as hypothesized above. The results obtained account for possible dual causality between economic growth and increase in number of Internet users, government consumption, life expectancy, inflation, current and capital expenditures on the armed forces, labour force rate, population density, people living in urban areas, R\&D investment, fertility rate and human capital accumulation (see León-González \& Montolio, 2015; Barro, 2015; Moral-Benito, 2012).

As Table 1 shows, we can validate the assumption of conditional economic convergence since the log of GDP per capita at the beginning of each period is negative for all the estimates. If we consider the other regressors, the lag of GDP per capita shows expected negative elasticity relative to economic growth for all estimates. Nevertheless, this outcome is only significant for the whole sample and non-OECD group, with coefficients $6.50 \%$ and $8.93 \%$, respectively, validating the conditional convergence' theoretical assumption. It means, in simple terms, that each economy converges to its own stationary state, and even it is possible the existence of groups of countries that convergence to similar long run equilibria. This outcome is only significant for the whole sample and non-OECD group, with coefficients $-4.80 \%$ and $-7.27 \%$, respectively. In addition, the estimated coefficient for Internet users is also positive and significant only for the whole sample $(0.06 \%)$ and for the non-OECD countries $(0.20 \%)$ The coefficient obtained for OECD countries is not significant and no different from zero. For the period analysed, these first results show that increases in access to information and knowledge diffusion through the Internet has an impact on growth in non-OECD countries nearly three times higher than that obtained for the whole sample, boosting economic convergence and confirming our first hypothesis ${ }^{9}$.

For the case of human capital accumulation, the estimates show a positive and significant coefficient, also for the whole sample and non-OECD countries. The same is observed for physical capital, population density, government consumption and dummies identifying the financial crisis and Muslim religion. Additionally, life expectancy shows positive and significant elasticity with economic growth and convergence, but only when all countries are considered. The variable has no significant effect on either developed or developing countries. Meanwhile, the variable that represents the difference between production value for a stock of minerals at world prices and their total production cost has a positive effect for all estimates performed, but only significant when the whole sample is considered. Further, the estimated coefficients for people living in urban areas and the English legal origin dummy show a positive and significant impact on growth for non-OECD economies only. In addition, for the whole sample, the fact that a country is landlocked is negatively related to economic growth and convergence. Finally, R\&D expenditure and military expenditure also affect economic growth negatively, but they are only significant for the whole sample and non-OECD countries.

\footnotetext{
${ }^{9}$ We have completed the system-GMM estimates by employing a different sample division to classify developed and developing countries: we have divided the sample into two new categories by using the median of per capita GDP in the first period of the analysis (1994-1996) as a threshold. The outcomes are similar to those previously obtained, in that developing countries benefit more from the increase in the number of internet users. These results are available upon request to the authors.
} 
Table 1. Panel data system GMM analysis

\begin{tabular}{|c|c|c|c|c|c|c|}
\hline Variables & $\begin{array}{l}\text { System } \\
\text { Whole }\end{array}$ & & System & & $\begin{array}{l}\text { System } \\
\text { Non-C }\end{array}$ & $\begin{array}{l}\text { M } 3 \\
\text { D }\end{array}$ \\
\hline$D_{i T-0}$ & $\begin{array}{c}0.0006 \\
(0.0002)\end{array}$ & $* * *$ & $\begin{array}{c}-0.0006 \\
(0.0010)\end{array}$ & & $\begin{array}{c}0.0020 \\
(0.0007)\end{array}$ & $* * *$ \\
\hline $\ln \left(y_{i 0}\right)$ & $\begin{array}{l}-0.0488 \\
(0.0052)\end{array}$ & $* * *$ & $\begin{array}{l}-0.0013 \\
(0.0476)\end{array}$ & & $\begin{array}{l}-0.0727 \\
(0.0094)\end{array}$ & $* * *$ \\
\hline$\phi E_{i t}$ & $\begin{array}{c}0.0661 \\
(0.0097)\end{array}$ & $* * *$ & $\begin{array}{c}0.0554 \\
(0.0643)\end{array}$ & & $\begin{array}{c}0.0973 \\
(0.0240)\end{array}$ & $* * *$ \\
\hline $\ln \left(s_{i t}\right)$ & $\begin{array}{c}0.0294 \\
(0.0074)\end{array}$ & $* * *$ & $\begin{array}{l}-0.0314 \\
(0.0884)\end{array}$ & & $\begin{array}{c}0.0300 \\
(0.0137)\end{array}$ & ** \\
\hline $\ln \left(1+n_{i, t}+\delta_{i, t}\right)$ & $\begin{array}{c}0.0765 \\
(0.0466)\end{array}$ & & $\begin{array}{c}0.3302 \\
(0.2396)\end{array}$ & & $\begin{array}{c}0.1087 \\
(0.0713)\end{array}$ & \\
\hline$P u b \_C_{i t}$ & $\begin{array}{c}0.3226 \\
(0.0315)\end{array}$ & $* * *$ & $\begin{array}{l}-0.3522 \\
(0.2580)\end{array}$ & & $\begin{array}{c}0.3335 \\
(0.0742)\end{array}$ & $* * *$ \\
\hline Opennes $_{i t}$ & $\begin{array}{c}0.0037 \\
(0.0058)\end{array}$ & & $\begin{array}{c}0.0483 \\
(0.0357)\end{array}$ & & $\begin{array}{l}-0.0112 \\
(0.0120)\end{array}$ & \\
\hline Democracy $_{i t}$ & $\begin{array}{c}0.0001 \\
(0.0003)\end{array}$ & & $\begin{array}{c}0.0096 \\
(0.0438)\end{array}$ & & $\begin{array}{l}-0.0010 \\
(0.0006)\end{array}$ & \\
\hline Democracy ${ }_{i t}^{2}$ & $\begin{array}{l}0.00001 \\
(0.0001)\end{array}$ & & $\begin{array}{c}0.0002 \\
(0.0027)\end{array}$ & & $\begin{array}{l}-0.0000 \\
(0.0000)\end{array}$ & \\
\hline $\ln \left(\right.$ Life_expect $\left.{ }_{i t}\right)$ & $\begin{array}{c}0.0958 \\
(0.0464)\end{array}$ & $* *$ & $\begin{array}{c}-0.2278 \\
(0.3854)\end{array}$ & & $\begin{array}{c}0.1480 \\
(0.0992)\end{array}$ & \\
\hline Crisis $_{i}$ & $\begin{array}{c}0.0159 \\
(0.0036)\end{array}$ & $* * *$ & $\begin{array}{l}-0.0145 \\
(0.0176)\end{array}$ & & $\begin{array}{c}0.0342 \\
(0.0056)\end{array}$ & $* * *$ \\
\hline Legal_english ${ }_{i}$ & $\begin{array}{c}0.0046 \\
(0.0066)\end{array}$ & & $\begin{array}{c}0.0034 \\
(0.0434)\end{array}$ & & $\begin{array}{c}0.0222 \\
(0.0096)\end{array}$ & ** \\
\hline Inflat $_{i t}$ & $\begin{array}{c}0.0932 \\
(0.0576)\end{array}$ & & $\begin{array}{c}0.1913 \\
(0.5818)\end{array}$ & & $\begin{array}{l}-0.0165 \\
(0.0866)\end{array}$ & \\
\hline Mil_exp ${ }_{i t}$ & $\begin{array}{l}-0.2836 \\
(0.0605)\end{array}$ & $* * *$ & $\begin{array}{c}0.0485 \\
(0.4604)\end{array}$ & & $\begin{array}{c}-0.4465 \\
(0.1161)\end{array}$ & $* * *$ \\
\hline Pop_dens $s_{i t}$ & $\begin{array}{c}0.0001 \\
(0.0000)\end{array}$ & $* * *$ & $\begin{array}{c}0.0001 \\
(0.0001)\end{array}$ & & $\begin{array}{c}0.0001 \\
(0.0000)\end{array}$ & $* * *$ \\
\hline Miner_rents $s_{i t}$ & $\begin{array}{c}0.0064 \\
(0.0013)\end{array}$ & $* * *$ & $\begin{array}{c}0.0076 \\
(0.0050)\end{array}$ & & $\begin{array}{c}0.0042 \\
(0.0026)\end{array}$ & \\
\hline Urban $_{i t}$ & $\begin{array}{l}-0.0445 \\
(0.0325)\end{array}$ & & $\begin{array}{l}-0.1844 \\
(0.1674)\end{array}$ & & $\begin{array}{c}0.0943 \\
(0.0462)\end{array}$ & $* *$ \\
\hline Labor $_{-}$force $_{i t}$ & $\begin{array}{c}0.0343 \\
(0.0212)\end{array}$ & & $\begin{array}{l}-0.0405 \\
(0.2733)\end{array}$ & & $\begin{array}{c}0.0343 \\
(0.1012)\end{array}$ & \\
\hline Fertility $_{i t}$ & $\begin{array}{l}-0.0052 \\
(0.0046)\end{array}$ & & $\begin{array}{c}0.0028 \\
(0.0629)\end{array}$ & & $\begin{array}{l}-0.0011 \\
(0.0098)\end{array}$ & \\
\hline$R \& D_{i t}$ & $\begin{array}{l}-0.0151 \\
(0.0042)\end{array}$ & $* * *$ & $\begin{array}{l}-0.0159 \\
(0.0241)\end{array}$ & & $\begin{array}{l}-0.0596 \\
(0.0243)\end{array}$ & $* *$ \\
\hline Muslim $_{i}$ & $\begin{array}{c}0.0784 \\
(0.0096)\end{array}$ & $* * *$ & $\begin{array}{c}0.3135 \\
(0.2255)\end{array}$ & & $\begin{array}{c}0.0806 \\
(0.0265)\end{array}$ & $* * *$ \\
\hline Latin $_{i}$ & $\begin{array}{c}0.0132 \\
(0.0113)\end{array}$ & & $\begin{array}{c}-0.1013 \\
(0.0762)\end{array}$ & & $\begin{array}{c}-0.0074 \\
(0.0207)\end{array}$ & \\
\hline
\end{tabular}


End of Table 1

\begin{tabular}{|c|c|c|c|c|c|}
\hline Variables & $\begin{array}{l}\text { System } \\
\text { Whole }\end{array}$ & & $\begin{array}{r}\text { System } \\
\text { OE }\end{array}$ & $\begin{array}{r}\text { System } \\
\text { Non-C }\end{array}$ & $\begin{array}{l}\text { MM } 3 \\
\text { CD }\end{array}$ \\
\hline Landlocked $_{i}$ & $\begin{array}{l}-0.0228 \\
(0.0076)\end{array}$ & $* * *$ & $\begin{array}{l}-0.0548 \\
(0.0397)\end{array}$ & $\begin{array}{c}0.0049 \\
(0.0144)\end{array}$ & \\
\hline$O E C D_{i}$ & $\begin{array}{l}-0.0079 \\
(0.0098)\end{array}$ & & - & - & \\
\hline$\beta_{0}$ & $\begin{array}{c}-0.0324 \\
(0.1826)\end{array}$ & & $\begin{array}{c}0.8938 \\
(1.7146)\end{array}$ & $\begin{array}{c}-0.1576 \\
(0.4162)\end{array}$ & \\
\hline
\end{tabular}

\begin{tabular}{|l|c|c|c|}
\hline \hline Observations & 511 & 207 & 304 \\
\hline Groups & 100 & 32 & 68 \\
\hline$A R(1)^{\dagger}$ & 0.155 & 0.002 & 0.174 \\
\hline$A R(2)^{\dagger}$ & 0.223 & 0.965 & 0.239 \\
\hline J-Hansen (Sargan) test $^{\dagger}$ & 1.000 & 1.000 & 1.000 \\
\hline $\begin{array}{l}\text { Difference-in-Sargan test } \\
(\text { C-test })^{\dagger}\end{array}$ & 0.913 & 1.000 & 0.972 \\
\hline
\end{tabular}

Note: ${ }^{*}$ - Significant at $0.1,{ }^{* *}-$ Significant at $0.05,{ }^{* *}$ - Significant at $0.01 .{ }^{\dagger} p$-values. Endogenous variables: Pub_C $C_{i t}, \ln \left(y_{i 0}\right), \phi E_{i t}, D_{i T-0}$, Fertility $_{i t}, M_{1}$ exp $_{i t}, R \& D_{i t}$, Urban $_{i t}$, Pop_dens ${ }_{i t}$, Inflat $t_{i t}$, Labor_force ${ }_{i t}$ and $\ln \left(\right.$ Life_expect $\left._{i t}\right)$.

These first results validate our theoretical framework, that an increase in the number of Internet users in a country is positively related to economic growth and thus to economic convergence, with a greater effect on developing countries. Nevertheless, the effect on developing countries is fairly small relative to the other regressors considered in the estimates, such as government consumption, human capital and the share of gross capital formation, for instance. We must therefore identify whether it is worth investing in improving Internet access to foster economic growth and convergence. As different covariates are introduced in the estimates in Table 1, it is important to find out which regressors are the most relevant in explaining the growth dynamics and convergence process among countries. Table 2 presents the outcomes via the BPMA approach, correcting for the problems of endogeneity identified in the system-GMM estimates. This approach is useful under model uncertainty to identify covariates that potentially have the greatest probability of belonging to the true model for estimating Eq. (4). This analysis will identify whether an increase in Internet users has been a determining factor in economic convergence.

The BPMA results in Table 2 show that the posterior inclusion probability (PIP) ${ }^{10}$ for Internet users in all estimates is $0.21-0.32$, which is $l^{11}$, thereby rejecting its relevance as

\footnotetext{
10 PIP is defined as the sum of the posterior model probabilities for all models that include the variable considered.

11 PIP between 0.75 and 1.00 indicates positive evidence for an effect (Eicher et al., 2012; Kass \& Raftery, 1995). However, this criterion is quite demanding and conservative. New applications suggest using "parsimoious model prior size $=m$ ", where $m$ is the true size of the model, and therefore, the relevant PIP is the one that exceeds the prior probability, that is, $m / k$, where $k$ is the number of variables included. Using this criterion, since we have $m=$ 6 and $k=26$, the cutoff PIP in our case would be $6 / 26=0.23$ (Peren Arin \& Braunfels, 2018; Leon-Gonzalez \& Vinayagathasan, 2015). Other authors establish a PIP cutoff of $=0.5$ (Desbordes et al., 2018).
} 
a determining factor in economic convergence during the period analysed ${ }^{12}$. This result contrasts with the significance obtained from the previous system-GMM analysis. Furthermore, the coefficients are close to zero and non-significant in all the estimates applied, which is different but not markedly so than those previously estimated in system-GMM. Therefore, according to these BPMA results, an increase in Internet users does not explain convergence among developed or developing countries during this period.

Regarding the other regressors, the BPMA analysis highlights that the log of GDP per capita in ' $t=0$ ' (with a PIP between 0.99-1.00), log of life expectancy (0.99-1.00), inflation (0.92-0.95), military expenditure (0.99-1.00), squared democracy (0.88-0.92), and labour force rate $(0.86-0.87)$ are the most important covariates explaining growth and convergence dynamics in all our estimates during the period analysed and are therefore the determinant factors to explaining these dynamics in both developed and developing countries.

Table 2. BPMA analysis, correcting endogeneity

\begin{tabular}{|c|c|c|c|c|c|c|}
\hline \multirow{2}{*}{ Variables } & \multicolumn{2}{|l|}{$\begin{array}{l}\text { BPMA } \\
\text { Whole }\end{array}$} & \multicolumn{2}{|l|}{$\begin{array}{l}\text { BPMA } \\
\text { OECD }\end{array}$} & \multicolumn{2}{|c|}{$\begin{array}{c}\text { BPMA } \\
\text { Non-OECD }\end{array}$} \\
\hline & $\begin{array}{l}\text { Posterior Mean. } \\
\text { (S.D.) }\end{array}$ & PIP & $\begin{array}{l}\text { Posterior Mean. } \\
\text { (S.D.) }\end{array}$ & PIP & $\begin{array}{l}\text { Posterior Mean. } \\
\text { (S.D.) }\end{array}$ & PIP \\
\hline$D_{i T-0}$ & $\begin{array}{c}0.0007 \\
(0.0012)\end{array}$ & 0.32 & $\begin{array}{c}0.0005 \\
(0.0009)\end{array}$ & 0.21 & $\begin{array}{c}0.0007 \\
(0.0012)\end{array}$ & 0.31 \\
\hline $\ln \left(y_{i 0}\right)$ & $\begin{array}{l}-0.0288 \\
(0.0055)\end{array}$ & 0.99 & $\begin{array}{l}-0.0286 \\
(0.0164)\end{array}$ & 1.00 & $\begin{array}{l}-0.0289 \\
(0.0057)\end{array}$ & 0.99 \\
\hline$\phi E_{i t}$ & $\begin{array}{c}0.0010 \\
(0.0038)\end{array}$ & 0.09 & $\begin{array}{c}0.0011 \\
(0.0039)\end{array}$ & 0.09 & $\begin{array}{c}0.0012 \\
(0.0041)\end{array}$ & 0.10 \\
\hline $\ln \left(s_{i t}\right)$ & $\begin{array}{c}0.0003 \\
(0.0023)\end{array}$ & 0.03 & $\begin{array}{c}0.0003 \\
(0.0023)\end{array}$ & 0.03 & $\begin{array}{c}0.0003 \\
(0.0025)\end{array}$ & 0.04 \\
\hline $\ln \left(1+n_{i, t}+\delta_{i, t}\right)$ & $\begin{array}{c}0.0018 \\
(0.0162)\end{array}$ & 0.03 & $\begin{array}{c}0.0017 \\
(0.0155)\end{array}$ & 0.03 & $\begin{array}{c}0.0022 \\
(0.0179)\end{array}$ & 0.03 \\
\hline$P u b_{-} C_{i t}$ & $\begin{array}{c}0.0018 \\
(0.0139)\end{array}$ & 0.03 & $\begin{array}{c}0.0017 \\
(0.0135)\end{array}$ & 0.03 & $\begin{array}{c}0.0024 \\
(0.0168)\end{array}$ & 0.04 \\
\hline Opennes $_{i t}$ & $\begin{array}{c}0.0156 \\
(0.0112)\end{array}$ & 0.72 & $\begin{array}{c}0.0183 \\
(0.0106)\end{array}$ & 0.82 & $\begin{array}{c}0.0160 \\
(0.0112)\end{array}$ & 0.74 \\
\hline Democracy $_{i t}$ & $\begin{array}{c}0.0001 \\
(0.0004)\end{array}$ & 0.09 & $\begin{array}{c}0.0001 \\
(0.0005)\end{array}$ & 0.13 & $\begin{array}{c}0.0001 \\
(0.0004)\end{array}$ & 0.09 \\
\hline Democracy $y_{i t}^{2}$ & $\begin{array}{l}-0.0001 \\
(0.0001)\end{array}$ & 0.92 & $\begin{array}{l}-0.0001 \\
(0.0001)\end{array}$ & 0.88 & $\begin{array}{l}-0.0001 \\
(0.0001)\end{array}$ & 0.92 \\
\hline $\ln \left(L i f e_{-} \exp e c t_{i t}\right)$ & $\begin{array}{c}0.0843 \\
(0.0165)\end{array}$ & 1.00 & $\begin{array}{c}0.0842 \\
(0.0164)\end{array}$ & 1.00 & $\begin{array}{c}0.0844 \\
(0.0171)\end{array}$ & 0.99 \\
\hline Crisis $_{i}$ & $\begin{array}{l}-0.0001 \\
(0.0021)\end{array}$ & 0.02 & $\begin{array}{l}-0.0001 \\
(0.0023)\end{array}$ & 0.02 & $\begin{array}{l}-0.0001 \\
(0.0019)\end{array}$ & 0.01 \\
\hline
\end{tabular}

\footnotetext{
12 This analysis is applied to the period from 1994 to 2014 . We consider the later period (2015-2017) as lost in the BPMA estimates, since we applied Helmert's transformation to eliminate fixed effects, thereby avoiding this source of endogeneity.
} 
End of Table 2

\begin{tabular}{|c|c|c|c|c|c|c|}
\hline \multirow{2}{*}{ Variables } & \multicolumn{2}{|l|}{$\begin{array}{l}\text { BPMA } \\
\text { Whole }\end{array}$} & \multicolumn{2}{|l|}{$\begin{array}{l}\text { BPMA } \\
\text { OECD }\end{array}$} & \multicolumn{2}{|c|}{$\begin{array}{c}\text { BPMA } \\
\text { Non-OECD }\end{array}$} \\
\hline & $\begin{array}{c}\text { Posterior Mean. } \\
\text { (S.D.) }\end{array}$ & PIP & $\begin{array}{c}\text { Posterior Mean. } \\
\text { (S.D.) }\end{array}$ & PIP & $\begin{array}{c}\text { Posterior Mean. } \\
\text { (S.D.) }\end{array}$ & PIP \\
\hline Legal_english $_{i}$ & $\begin{array}{c}0.0033 \\
(0.0100)\end{array}$ & 0.12 & $\begin{array}{c}0.0029 \\
(0.0093)\end{array}$ & 0.11 & $\begin{array}{c}0.0035 \\
(0.0101)\end{array}$ & 0.13 \\
\hline Inflat $_{i t}$ & $\begin{array}{c}0.0262 \\
(0.0093)\end{array}$ & 0.94 & $\begin{array}{c}0.0253 \\
(0.0101)\end{array}$ & 0.92 & $\begin{array}{c}0.0262 \\
(0.0092)\end{array}$ & 0.95 \\
\hline Mil_exp ${ }_{i t}$ & $\begin{array}{c}0.7458 \\
(0.1672) \\
\end{array}$ & 0.99 & $\begin{array}{c}0.7297 \\
(0.1695)\end{array}$ & 0.99 & $\begin{array}{c}0.7461 \\
(0.1682)\end{array}$ & 1.00 \\
\hline Pop_dens $s_{i t}$ & $\begin{array}{l}-0.0001 \\
(0.0001)\end{array}$ & 0.05 & $\begin{array}{l}-0.0001 \\
(0.0001)\end{array}$ & 0.06 & $\begin{array}{l}-0.0001 \\
(0.0001)\end{array}$ & 0.06 \\
\hline Miner_rents $s_{i t}$ & $\begin{array}{l}-0.0001 \\
(0.0001)\end{array}$ & 0.02 & $\begin{array}{l}-0.0001 \\
(0.0003)\end{array}$ & 0.02 & $\begin{array}{l}-0.0001 \\
(0.0003)\end{array}$ & 0.02 \\
\hline Urban $_{i t}$ & $\begin{array}{c}0.0002 \\
(0.0029)\end{array}$ & 0.02 & $\begin{array}{c}0.0001 \\
(0.0024)\end{array}$ & 0.02 & $\begin{array}{c}0.0003 \\
(0.0032)\end{array}$ & 0.02 \\
\hline Labor $_{-}$force $_{i t}$ & $\begin{array}{l}-0.0885 \\
(0.0451)\end{array}$ & 0.86 & $\begin{array}{l}-0.0903 \\
(0.0443)\end{array}$ & 0.87 & $\begin{array}{l}-0.0887 \\
(0.0449)\end{array}$ & 0.86 \\
\hline Fertility $_{i t}$ & $\begin{array}{l}-0.0001 \\
(0.0008)\end{array}$ & 0.04 & $\begin{array}{l}-0.0001 \\
(0.0009)\end{array}$ & 0.05 & $\begin{array}{l}-0.0001 \\
(0.0008)\end{array}$ & 0.04 \\
\hline$R \& D_{i t}$ & $\begin{array}{c}0.0001 \\
(0.0008)\end{array}$ & 0.02 & $\begin{array}{c}0.0001 \\
(0.0007)\end{array}$ & 0.02 & $\begin{array}{c}0.0001 \\
(0.0008)\end{array}$ & 0.02 \\
\hline Muslim $_{i}$ & $\begin{array}{l}-0.0001 \\
(0.0026)\end{array}$ & 0.02 & $\begin{array}{l}-0.0002 \\
(0.0028)\end{array}$ & 0.02 & $\begin{array}{l}-0.0002 \\
(0.0029)\end{array}$ & 0.02 \\
\hline $\operatorname{Latin}_{i}$ & $\begin{array}{c}0.0024 \\
(0.0090)\end{array}$ & 0.09 & $\begin{array}{c}0.0017 \\
(0.0074)\end{array}$ & 0.06 & $\begin{array}{c}0.0021 \\
(0.0084)\end{array}$ & 0.08 \\
\hline Landlocked $_{i}$ & $\begin{array}{c}0.0001 \\
(0.0023)\end{array}$ & 0.02 & $\begin{array}{c}0.0001 \\
(0.0025)\end{array}$ & 0.02 & $\begin{array}{c}0.0002 \\
(0.0026)\end{array}$ & 0.02 \\
\hline$O E C D_{i}$ & $\begin{array}{c}0.0004 \\
(0.0038)\end{array}$ & 0.03 & - & & - & \\
\hline Observations & \multicolumn{2}{|l|}{511} & \multicolumn{2}{|l|}{207} & \multicolumn{2}{|l|}{304} \\
\hline Groups & \multicolumn{2}{|l|}{100} & \multicolumn{2}{|l|}{32} & \multicolumn{2}{|l|}{68} \\
\hline Model space & \multicolumn{2}{|l|}{$2^{24}$} & \multicolumn{2}{|l|}{$2^{23}$} & \multicolumn{2}{|l|}{$2^{23}$} \\
\hline
\end{tabular}

Note: Endogenous variables: $P u b_{-} C_{i t}, \ln \left(y_{i 0}\right), \phi E_{i t}, D_{i T-0}, F e r t i l i t y_{i t}, M i l_{-} \exp _{i t}, R \& D_{i t}$, Urban $n_{i t}$, Pop_dens ${ }_{i t}$, Inflat ${ }_{i t}$, Labor_force ${ }_{i t}$ and $\ln \left(\right.$ Life $\left._{\text {e expect }}{ }_{i t}\right)$. PIP between 0.75 and 1.00 indicates positive evidence for a determinant effect of the variable (Eicher et al., 2012; Kass \& Raftery, 1995). Table A.3 in Appendix provides the F-test for testing validity of instruments for endogenous covariates considered in BPMA.

The results obtained are relevant as they help us to better understand the impact of the Internet as a channel of information and knowledge diffusion on growth and convergence. Moreover, these outcomes support the contradictory results obtained in the literature regarding this relationship when empirical models are affected by model uncertainty. Nevertheless, our empirical results could also be affected by other limitations such as the time span considered to perform our analysis. Therefore, it is likely that the impact of the Internet on growth 
and convergence is only observed during a specific period, and therefore not a regular effect. To avoid this limitation, as a robustness check of our previous BPMA estimates, we perform several new BPMA estimates of (4) considering different time spans in order to test whether the non-determinant effect of the Internet on convergence is maintained for different periods. These new estimates are performed only with the whole sample. The new periods analysed are split into the following three-year periods:

1. 1994-1996, and 1997-1999 (1994-1999)

2. 1994-1996, 1997-1999, and 2000-2002 (1994-2002),

3. 1994-1996, 1997-1999, 2000-2002, and 2003-2005 (1994-2005),

4. 1994-1996, 1997-1999, 2000-2002, 2003-2005, and 2006-2008 (1994-2008),

5. 1994-1996, 1997-1999, 2000-2002, 2003-2005, 2006-2008, and 2009-2011 (1994-2011)

Table 3 presents the outcomes obtained for the estimates of the Internet coefficient. These outcomes show a different level of relevance on convergence depending on the period. For the time span 1994-2011, our results show that the Internet is a determinant factor for explaining growth (and convergence) with a PIP of $0.89^{13}$. In contrast, for the other periods

Table 3. BPMA Estimates for internet coefficient $\left(D_{i T-0}\right)$ for the different period considered, correcting endogeneity

\begin{tabular}{|c|c|c|}
\hline \multirow{2}{*}{ Variables } & \multicolumn{2}{|c|}{ BPMA Whole } \\
\cline { 2 - 3 } & Posterior Mean. (S.D.) & PIP \\
\hline \multirow{2}{*}{$(1994-1999)$} & $\begin{array}{c}0.0006 \\
(0.0015)\end{array}$ & 0.20 \\
\hline$(1994-2002)$ & $\begin{array}{c}0.0002 \\
(0.0006)\end{array}$ & 0.07 \\
\hline$(1994-2005)$ & $\begin{array}{c}0.0002 \\
(0.0006)\end{array}$ & 0.09 \\
\hline$(1994-2008)$ & $\begin{array}{c}0.0021 \\
(0.0018)\end{array}$ \\
\hline$(1994-2011)$ & $\begin{array}{c}0.0027 \\
(0.0012)\end{array}$ & 0.89 \\
\hline
\end{tabular}

Note: Endogenous variables: $P u b_{-} C_{i t}, \ln \left(y_{i 0}\right), \phi E_{i t}, D_{i T-0}, F e r t i l i t y_{i t}, M i l_{-} \exp _{i t}, R \& D_{i t}, U r b a n_{i t}$, Pop_dens $i_{i t}$, Inflat ${ }_{i t}$, Labor $_{-}$force $_{i t}$ and $\ln \left(\right.$ Life_expect $\left._{i t}\right)$. PIP between 0.75 and 1.00 indicates positive evidence for a determinant effect of the variable (Eicher et al., 2012; Kass \& Raftery, 1995).

\footnotetext{
${ }^{13}$ Furthermore, we have performed new estimates using a different sample division to classify developed and developing countries, using the median of GDP per capita in the first period of the analysis (1994-1996) as a threshold. The outcomes obtained show that the only period in which the Internet is a determinant variable for explaining growth is during the time span 1994-2011, with a PIP of 0.91. In addition, and as a robustness check, we have performed new estimates for the same time span to test whether different sample selections could affect the results. In this regard, we have run new estimations and in each one we have dropped one different country from the initial pool of 100 countries (see Table A.2 in Appendix). The outcomes show that the estimated PIP for the Internet varies considerably in every estimate run. For instance, when Australia is dropped, the PIP increases by $9.146 \%$. When Nigeria is dropped, the PIP decreases by $-11.312 \%$ and draws near to the level at which the Internet would be considered a non-determinant for explaining growth (0.78). These new estimates show the sensitivity of the outcomes to the sample composition. The new estimates are available upon request to the authors.
} 
(1994-1999, 1994-2002, 1994-2005, and 1994-2008) the results show a PIP below 0.75, similar to the results obtained previously for the whole period (1994-2014; see Table 2), confirming that when we divide the time span in different subperiods we must reject the relevance of the Internet on growth and convergence.

In contrast with Spar (1999, p. 358), who declared that "it is in the developing world where the positive externalities from the internet [as a channel for knowledge diffusion] promise to be most powerful [on its economic growth]", our evidence confirms that, when we control for model uncertainty in our empirical analysis and test for different time spans, Internet diffusion must not be included as one of the variables in the true model for explaining convergence among developed or developing countries.

\section{Conclusions}

The Internet as a recent mass media channel has undoubtedly improved the diffusion of information and knowledge across countries, reducing both the time to reach such an audience and the costs to access it. This could help in recovering the well-known idea from economic growth literature of "innovation sharing processes" (Baumol, 1986). Motivated by limited knowledge and the ambiguous results of previous research on the effect of the Internet on economic growth and convergence, our aim in this paper was to empirically determine whether an increase in access to the Internet, as a channel of information and knowledge diffusion measured by the number of Internet users, is a determining factor in economic growth and convergence across countries. To do so we state a conditional convergence growth model assessed empirically using a Bayesian panel data model averaging approach (BPMA), which is remarkably useful under model uncertainty.

We have performed several estimations to test the importance of an increase in access to the Internet as an explaining factor in growth and convergence. All estimates show a high sensitivity when model uncertainty is considered. The results help to explain the contradictory and ambiguous results of previous literature on the effect of the Internet on economic growth and convergence. Thanks to this study's methodological novelty, our results, after correcting for problems of endogeneity, indicate that the probability of inclusion of Internet diffusion in the true growth model is far below the minimum needed. Therefore, it is not an element in determining economic growth in developing or developed countries and cannot be considered a determinant factor in economic convergence under the conditional assumption.

Although this study provides new empirical evidence and helps to clarify the contradictory results in previous literature, it may have some limitations. Specifically, the proxy that we have used to measure "information and knowledge diffusion" is not the most appropriate, and results in a lack of robustness in our results. The number of Internet hosts (IHs) could be a more relevant variable to measure a country's Internet diffusion and to investigate its effect on economic growth and convergence. Unfortunately, the lack of data on IHs for most countries in the world limits our capacity to identify the "true model", which ultimately should be oriented towards effective absorptive capacity. Therefore, further research is needed to continue these investigations and to fill in these gaps. Finally, another extension and 
future direction for this line of research would be to analyse the role of internet adoption and diffusion on cross-country convergence on total factor productivity (TFP) instead of GDP per capita. In this sense, it is likely that the internet has helped to spread new knowledge and innovations globally and boosting technological progress (Baumol, 1986). The previous research in that field have found the ICT has a positive effect on TFP (Bollou \& Ngwenyama, 2008), but internet adoption has not being included directly there.

\section{Disclosure statement}

The authors declare not having any competing financial, professional, or personal interests from other parties.

\section{References}

Andrés, L., Cuberes, D., Diouf, M., \& Serebrisky, T. (2010). The diffusion of the Internet: A cross-country analysis. Telecommunications Policy, 34(5-6), 323-340. https://doi.org/10.1016/j.telpol.2010.01.003

Appiah-Otoo, I., \& Song, N. (2021). The impact of ICT on economic growth-Comparing rich and poor countries. Telecommunications Policy, 45(2), 102082. https://doi.org/10.1016/j.telpol.2020.102082

Arellano, M., \& Bover, S. (1995). Another look at instrumental variables estimation of error-component models. Journal of Econometrics, 68(1), 29-51. https://doi.org/10.1016/0304-4076(94)01642-D

Barro, R. J. (1996). Determinants of economic growth: A cross-country empirical study (NBER Working paper 5698). Massachusetts, CA. https://doi.org/10.3386/w5698

Barro, R. J. (2015). Convergence and modernization. The Economic Journal, 125(585), 911-942. https://doi.org/10.1111/ecoj.12247

Barro, R. J., \& Sala-i-Martin, X. (2004). Economic growth (2 $2^{\text {nd }}$ ed.). The MIT Press.

Baumol, W. J. (1986). Productivity growth, convergence, and welfare: What the long-run data show. The American Economic Review, 76(5), 1072-1085.

Benoit, E. (1978). Growth and defense in developing countries. Economic Development and Cultural Change, 26(2), 271-280. https://doi.org/10.1086/451015

Bertschek, I., Briglauer, W., Hüschelrath, K., Kauf, B., \& Niebel, T. (2015). The economic impacts of broadband internet: A survey. Review of Network Economics, 14(4), 201-227. https://doi.org/10.1515/rne-2016-0032

Blundell, R., \& Bond, S. (1998). Initial conditions and moment restrictions in dynamic panel-data models. Journal of Econometrics, 87(1), 115-143. https://doi.org/10.1016/S0304-4076(98)00009-8

Bollou, F., \& Ngwenyama, O. (2008). Are ICT investments paying off in Africa? An analysis of total factor productivity in six West African countries from 1995 to 2002. Information Technology for Development, 14(4), 294-307. https://doi.org/10.1002/itdj.20089

Cardona, M., Kretschmer, T., \& Strobel, T. (2013). ICT and productivity: Conclusions from the empirical literature. Information Economics and Policy, 25(3), 109-125. https://doi.org/10.1016/j.infoecopol.2012.12.002

Caselli, F., \& Coleman, W. J. (2001). Cross-country technology diffusion: The case of computers. The American Economic Review, 91(2), 328-335. https://doi.org/10.1257/aer.91.2.328

Choi, C., \& Yi, M. H. (2009). The effect of the Internet on economic growth: Evidence from crosscountry panel data. Economics Letters, 105(1), 39-41. https://doi.org/10.1016/j.econlet.2009.03.028

Choi, C., \& Yi, M. H. (2018). The Internet, R\&D expenditure and economic growth. Applied Economics Letters, 25(4), 264-267. https://doi.org/10.1080/13504851.2017.1316819 
Cortright, J. (2001). New growth theory, technology and learning. (Reviews of economic development literature and practice No. 4). U.S. Economic Development Administration, Portland (US).

Dasgupta, S., Lall, S., \& Wheeler, D. (2005). Policy reform, economic growth, and the digital divide. Oxford Development Studies, 33(2), 229-243. https://doi.org/10.1080/13600810500137889

Dedrick, J., Kraemer, K. L., \& Shih, E. (2013). Information technology and productivity in developed and developing countries. Journal of Management Information Systems, 30(1), 97-122. https://doi.org/10.2753/MIS0742-1222300103

Desbordes, R., Koop, G., \& Vicard, V. (2018). One size does not fill all... panel data: Bayesian model averaging and data poolability. Economic Modelling, 75, 364-376.

https://doi.org/10.1016/j.econmod.2018.07.009

Dowrick, S., \& Rogers, M. (2002). Classical and technological convergence: Beyond the Solow-Swan growth model. Oxford Economic Papers, 54(3), 369-385. https://doi.org/10.1093/oep/54.3.369

Eicher, T., Henn, C., \& Papageorgiou, C. (2012). Trade creation and diversion revisited: Accounting for model uncertainty and natural trading partner effects. Journal of Applied Econometrics, 27(2), 296-321. https://doi.org/10.1002/jae.1198

Feenstra, R. C., Inklaar, R., \& Timmer, M. P. (2015). The next generation of the Penn World Table. American Economic Review, 105(10), 3150-3182. https://doi.org/10.1257/aer.20130954

Haini, H. (2019). Internet penetration, human capital and economic growth in the ASEAN economies: Evidence from a translog production function. Applied Economics Letters, 26(21), 1774-1778. https://doi.org/10.1080/13504851.2019.1597250

Harris, R., \& Yan, J. (2019). The measurement of absorptive capacity from an economic perspective: Definition, measurement and importance. Journal of Economic Survey, 33(3), 729-756. https://doi.org/10.1111/joes.12296

Kass, R. E., \& Raftery, A. E. (1995). Bayes factors. Journal of the American Statistical Association, 90(430), 773-795. https://doi.org/10.1080/01621459.1995.10476572

Kraay, A. (2015). Weak instruments in growth regressions implications for recent cross-country evidence on inequality and growth (Policy Research Working Paper 7494). Washington, D.C. https://doi.org/10.1596/1813-9450-7494

La Porta, R., Lopez-de-Silanes, F., Shleifer, A., \& Vishny, R. (1999). The quality of government. The Journal of Law, Economics, and Organization, 15(1), 222-279. https://doi.org/10.1093/jleo/15.1.222

León-González, R., \& Montolio, D. (2015). Endogeneity and panel data in growth regressions: A Bayesian model averaging approach. Journal of Macroeconomics, 46, 23-39. https://doi.org/10.1016/j.jmacro.2015.07.003

Leon-Gonzalez, R., \& Vinayagathasan, T. (2015). Robust determinants of growth in Asian developing economies: A Bayesian panel data model averaging approach. Journal of Asian Economics, 36, 34-46. https://doi.org/10.1016/j.asieco.2014.12.001

Li, R., \& Shiu, A. (2012). Internet diffusion in China: A dynamic panel data analysis. Telecommunications Policy, 36(10-11), 872-887. https://doi.org/10.1016/j.telpol.2012.06.004

Lundvall, B. Å., Vang, J., \& Joseph, K. J. (2009). Innovation system research and developing countries. In B. Å. Lundvall, K. J. Joseph, C. Chaminade, \& J. Vang (Eds.), Handbook of innovation systems and developing countries: Building domestic capabilities in a global setting (pp. 1-32). Edward Elgar Publishing. https://doi.org/10.4337/9781849803427

Lundvall, B. A. (2017). The learning economy and the economics of hope. Anthem Press. https://doi.org/10.26530/OAPEN_626406

Madon, S. (2000). The Internet and socio-economic development: Exploring the interaction. Information Technology \& People, 13(2), 85-101. https://doi.org/10.1108/09593840010339835

Mankiw, N. G., Romer, D., \& Weil, D. A. (1992). Contribution to the empirics of economic growth. The Quarterly Journal of Economics, 107(2), 407-437. https://doi.org/10.2307/2118477 
Maurseth, P. B. (2018). The effect of the Internet on economic growth: Counter-evidence from crosscountry panel data. Economics Letters, 172, 74-77. https://doi.org/10.1016/j.econlet.2018.08.034

Moral-Benito, E. (2012). Determinants of economic growth: A Bayesian panel data approach. The Review of Economics and Statistics, 94(2), 566-579. https://doi.org/10.1162/REST_a_00154

Moral-Benito, E., Allison, P., \& Williams, R. (2019). Dynamic panel data modelling using maximum likelihood: An alternative to Arellano-Bond. Applied Economics, 51(20), 2221-2232. https://doi.org/10.1080/00036846.2018.1540854

Myovella, G., Karacuka, M., \& Haucap, J. (2020). Digitalization and economic growth: A comparative analysis of Sub-Saharan Africa and OECD economies. Telecommunications Policy, 44(2), 101856. https://doi.org/10.1016/j.telpol.2019.101856

Niebel, T. (2018). ICT and economic growth - Comparing developing, emerging and developed countries. World Development, 104, 197-211. https://doi.org/10.1016/j.worlddev.2017.11.024

OECD. (2016). Economic and social benefits of internet openness. Directorate for Science, Technology and Innovation Committee on Digital Economic Policy.

Oyelaran-Oyeyinka, B., \& Lal, K. (2005). Internet diffusion in sub-Saharan Africa: A cross-country analysis. Telecommunications Policy, 29(7), 507-527. https://doi.org/10.1016/j.telpol.2005.05.002

Papaioannou, S. K., \& Dimelis, S. P. (2007). Information technology as a factor of economic development: Evidence from developed and developing countries. Economics of Innovation and New Technology, 16(3), 179-194. https://doi.org/10.1080/10438590600661889

Pélissié du Rausas, M., Manyika, J., Hazan, E., Bughin, J., Chui, M., \& Said, R. (2011). Internet matters: The Net's sweeping impact on growth, jobs and prosperity. McKinsey Global Institute, New York.

Peren Arin, K., \& Braunfels, E. (2018). The resource curse revisited: A Bayesian model averaging approach. Energy Economics, 70, 170-178. https://doi.org/10.1016/j.eneco.2017.12.033

Romer, D. (2006). Advanced macroeconomics ( ${ }^{\text {rd }}$ ed.). McGraw-Hill.

Romer, P. M. (1987). Growth based on increasing returns due to specialization. The American Economic Review, 77(2), 56-62.

Röller, H., \& Waverman, L. (2001). Telecommunications infrastructure and economic development: A simultaneous approach. American Economic Review, 91(4), 909-923. https://doi.org/10.1257/aer.91.4.909

Salahuddin, M., \& Gow, J. (2016). The effects of Internet usage, financial development and trade openness on economic growth in South Africa: A time series analysis. Telematics and Informatics, 33(4), 1141-1154. https://doi.org/10.1016/j.tele.2015.11.006

Sala-i-Martin, X. (1995). The classical approach to convergence analysis (Center Discussion Paper No. 734). Yale University.

Sala-i-Martin, X. (1997). I just ran two million regressions. American Economic Review, 87(2), 178-183.

Sala-i-Martin, X., Doppelhofer, G., \& Miller, R. (2004). Determinants of long-term growth: A Bayesian averaging of classical estimates (BACE) approach. American Economic Review, 94(4), 813-835. https://doi.org/10.1257/0002828042002570

Spar, D. L. (1999). The public face of cyberspace. In I. Kaul, I. Grunberg, \& M. Stern (Eds.), Global public goods: International Cooperation in the $21^{\text {st }}$ Century (pp. 344-362). United Nations Development Programme. Oxford University Press. https://doi.org/10.1093/0195130529.003.0017

Stanley, T. D., Doucouliaagos, H., \& Steel, P. (2018). Does ICT generate economic growth? A metaregression analysis. Journal of Economic Survey, 32(3), 705-726. https://doi.org/10.1111/joes.12211

Stiglitz, J. E. (1999). Knowledge as a global public good. In In I. Kaul, I. Grunberg, \& M. Stern (Eds.), Global public goods: International Cooperation in the $21^{\text {st }}$ Century (pp. 308-325). United Nations Development Programme. Oxford University Press. https://doi.org/10.1093/0195130529.003.0015 
$\mathrm{Vu}, \mathrm{K} . \mathrm{M}$. (2019). The internet-growth link: An examination of studies with conflicting results and new evidence on the network effect. Telecommunications Policy, 43(5), 474-483. https://doi.org/10.1016/j.telpol.2019.04.002

Vu, K. M., \& Asongu, S. (2020). Backwardness advantage and economic growth in the information age: A cross-country empirical study. Technological Forecasting and Social Change, 159, 120197. https://doi.org/10.1016/j.techfore.2020.120197

Vu, K. M., Hanafizadeh, P., \& Bohlin, E. (2020). ICT as a driver of economic growth: A survey of the literature and directions for future research. Telecommunications Policy, 44(2), 101922. https://doi.org/10.1016/j.telpol.2020.101922

World Bank. (2018). World Development Indicators 2018. Oxford University Press. https://data.worldbank.org/indicator/IT.NET.USER.ZS

\section{APPENDIX}

In the following section we define mathematically the theoretical framework which leads to a potential equation to be estimated in order to test the two hypotheses set out. Let's consider a per capita Cobb-Douglas production function with a Hicks-neutral technical change that incorporates the effect of human capital:

$$
y_{i t}=A_{i t} \cdot k_{i t}^{\alpha} \cdot\left[e^{\phi E_{i t}}\right]^{1-\alpha}, 0<\alpha<1
$$

where $y_{i t}$ is the flow of output per capita produced in an economy $i$ at time $t(t=0, \ldots, T), k_{i t}$ is physical capital per capita, $E_{i t}$ is years of schooling, $\phi$ is rate of return of schooling (Romer, 2001; Barro, 2015), and $A_{i t}$ is technological progress. In line with the conditional economic growth model, the latter depends on (Barro \& Sala-i-Martin, 2004):

$$
A_{i t}=A_{i 0} \cdot e^{g_{i t}}
$$

where the rate of growth of technology $\left(g_{i t}\right)$ is expressed in the fashion of Dowrick and Rogers (2002):

$$
g_{i t}=g_{i}+g_{t}+\mu \cdot D_{i t},
$$

where $g_{i}$ is the country heterogeneity of technological progress ${ }^{14}, g_{t}$ the period-specific component, $D_{i t}$ the diffusion of information and knowledge or technological progress in the country $i$, and $\mu$ the return of diffusion. We focus our attention on the term $D_{i t}$. The assumption is that one country will increase its technological progress if it improves access to channels that allow for better diffusion of information and knowledge (Barro, 2015). In this paper, the role of the Internet is essential in defining $D_{i t}$ because it is the channel for both information and knowledge diffusion, which boosts technological progress through the absorption of innovations and new technology via the production process (OECD, 2016). This change in turn increases both economic growth and convergence.

\footnotetext{
${ }^{14}$ Differences in technological progress across economies can be related to the quality of institutions i.e. property rights, efficiency of the tax system or policies that determine the domestic rate of innovation, which may be fixed during the period of analysis (Barro, 2015).
} 
Let $s_{i t}$ be the economy's savings via the per capita physical capital input, $\delta_{i}$ its rate of depreciation, and $n_{i}$ the rate of population growth -similar to the conditional convergence approach defined by MRW (1992). The law of motion for per capita physical capital is then determined by:

$$
\dot{k}_{i t}=s_{i t} \cdot y_{i t}-\left(n_{i}+\delta_{i}\right) \cdot k_{i t} .
$$

Using (1) and (4), we can determine the level of $k_{i t}$ in the steady state, which is defined by $k_{i}^{*}$ for $\dot{k}_{i t}=0$, taking:

$$
k_{i}^{\star}=e^{\phi E_{i t}} \cdot\left(\frac{s_{i t} \cdot A_{i t}}{n_{i}+\delta_{i}}\right)^{\frac{1}{1-\alpha}} .
$$

Once we define $k_{i}^{*}$, we can combine Eqs (1), (2) and (5) to obtain the steady-state level of flow of per capita output produced in an economy:

$$
\begin{gathered}
y_{i}^{*}=A_{i t} \cdot k_{i}^{*} \cdot\left[e^{\phi E_{i t}}\right]^{1-\alpha} ; \\
y_{i}^{*}=\left(A_{i 0} \cdot e^{g_{i t}}\right)^{\frac{1}{1-\alpha}} \cdot e^{\phi E_{i t}} \cdot\left(\frac{s_{i t}}{n_{i}+\delta_{i}}\right)^{\frac{\alpha}{1-\alpha}} .
\end{gathered}
$$

We seek to analyse the effect of Internet as a channel for the diffusion of both information and knowledge in the economic convergence of an economy to its steady state (determined by considering the "conditional convergence" phenomenon). We can thus apply an approximation around the steady state for the per capita output produced in an economy using the Taylor-series rule and the law of motion for the country's economic growth (MRW, 1992):

$$
\begin{aligned}
& \frac{d \ln \left(y_{i t}\right)}{d t}=\left(\ln \left(y_{i T}\right)-\ln \left(y_{i 0}\right)\right) \cdot t^{-1}=\lambda_{i} \cdot\left[\ln \left(y_{i}^{*}\right)-\ln \left(y_{i 0}\right)\right] \\
& \left(\ln \left(y_{i T}\right)-\ln \left(y_{i 0}\right)\right) \cdot t^{-1}=\left(1-e^{-\lambda_{i} \cdot t}\right) \cdot t^{-1} \cdot \ln \left(y_{i}^{*}\right)-\left(1-e^{-\lambda_{i} \cdot t}\right) \cdot t^{-1} \cdot \ln \left(y_{i 0}\right),
\end{aligned}
$$

where $\lambda_{i}$ is the rate of convergence for one country around its steady state:

$$
\lambda_{i}=\left(n_{i}+\delta_{i}\right) \cdot(1-\alpha) .
$$

Finally, using Eqs (3), (6.2) and (7.2), and considering that $\left(\ln \left(y_{i T}\right)-\ln \left(y_{i 0}\right)\right)=\psi_{i T-0}$, we obtain the equation that we will assess empirically:

$$
\begin{aligned}
& \psi_{i T-0}=\left(1-e^{-\lambda_{i} \cdot t}\right) \cdot\left(\frac{1}{1-\alpha}\left(\ln \left(A_{i 0}\right)+g_{i}+g_{T}+\mu \cdot D_{i T-0}\right)+\right. \\
& \left.\alpha \cdot \ln \left(s_{i t}\right)-\alpha \cdot \ln \left(n_{i}+\delta_{i}\right)+\phi E_{i t}-\ln \left(y_{i 0}\right)\right) .
\end{aligned}
$$

In accordance with the goals of this paper, Eq. (9) represents theoretically the expected positive relationship between economic growth and diffusion of information and knowledge via Internet for each country:

$$
\frac{\partial \psi_{i T-0}}{\partial D_{i T-0}}=\frac{\left(1-e^{-\lambda_{i} \cdot t}\right)}{1-\alpha} \cdot \mu>0
$$

The theoretical relationship contained in Eq. (10) is our first hypothesis: The Internet is a determining factor in explaining economic convergence across countries. 
Table A.1. List of variables considered for the estimates

\begin{tabular}{|c|c|c|}
\hline Variable & Brief description & Source \\
\hline $\ln \left(y_{i t}\right)$ & Output-side real GDP at current PPPs (in mil. 2011US\$). & PWT \\
\hline $\ln \left(s_{i t}\right)$ & $\begin{array}{l}\text { Three-year averages (for period } t \text { to } t-3 \text { ) for share of gross } \\
\text { capital formation at current PPPs. }\end{array}$ & PWT \\
\hline$n_{i, t}$ & $\begin{array}{l}\text { Three-year averages (for period } t \text { to } t-3 \text { ) for growth rate for } \\
\text { number of persons engaged. }\end{array}$ & PWT \\
\hline$\delta_{i, t}$ & $\begin{array}{l}\text { Three-year averages (for period } t \text { to } t-3 \text { ) for average } \\
\text { depreciation rate of capital stock. }\end{array}$ & PWT \\
\hline$D_{i T-0}$ & $\begin{array}{l}\text { Three-year variation (for period } t \text { to } t-3 \text { ) in number of } \\
\text { individuals per } 100 \text { people who have used Internet from any } \\
\text { location in last } 3 \text { months in every country. }\end{array}$ & WDI \\
\hline$\phi E_{i t}$ & $\begin{array}{l}\text { Three-year averages (for period } t \text { to } t-3 \text { ) for human capital } \\
\text { index, based on years of schooling and returns to education. }\end{array}$ & PWT \\
\hline$P u b_{-} C_{i t}$ & $\begin{array}{l}\text { Three-year averages (for period } t \text { to } t-3 \text { ) for share of } \\
\text { government consumption at current PPPs. }\end{array}$ & PWT \\
\hline Democracy $_{i t}$ & $\begin{array}{l}\text { Three-year averages (for period } t \text { to } t-3 \text { ) for scores on } \\
\text { democracy. }\end{array}$ & FreeH \\
\hline $\ln \left(L i f e_{-} \exp e c t_{i t}\right)$ & $\begin{array}{l}\text { Three-year averages (for period } t \text { to } t-3 \text { ) for life expectancy at } \\
\text { birth. }\end{array}$ & WDI \\
\hline Legal_english $h_{i}$ & Dummy identifying origin of the legal system in a country. & $\begin{array}{l}\text { La Porta et al. } \\
\text { (1999) }\end{array}$ \\
\hline Opennes $_{i t}$ & $\begin{array}{l}\text { Three-year averages (for period } t \text { to } t-3 \text { ) for openness rate at } \\
\text { current PPPs. }\end{array}$ & PWT \\
\hline Inflat $_{i t}$ & $\begin{array}{l}\text { Three-year geometric averages (for period } t \text { to } t-3 \text { ) for annual } \\
\text { growth rate of GDP implicit deflator. }\end{array}$ & WDI \\
\hline Mil_expit & $\begin{array}{l}\text { Three-year averages (for period } t \text { to } t-3 \text { ) for all current } \\
\text { and capital expenditures on the armed forces, including } \\
\text { peacekeeping forces; defense ministries and other government } \\
\text { agencies engaged in defense projects; paramilitary forces, } \\
\text { if these are judged to be trained and equipped for military } \\
\text { operations; and military space activities. }\end{array}$ & SIPRI \\
\hline Pop_dens $s_{i t}$ & $\begin{array}{l}\text { Three-year averages (for period } t \text { to } t-3 \text { ) for people per square } \\
\mathrm{km} \text { of land area. }\end{array}$ & WDI \\
\hline Miner_rents $s_{i t}$ & $\begin{array}{l}\text { Three-year averages (for period } t \text { to } t-3 \text { ) for difference } \\
\text { between value of production for a stock of minerals at world } \\
\text { prices and their total cost of production. }\end{array}$ & WDI \\
\hline $\operatorname{Urban}_{i t}$ & $\begin{array}{l}\text { Three-year averages (for period } t \text { to } t-3 \text { ) for people living in } \\
\text { urban areas as defined by national statistics offices. }\end{array}$ & WDI \\
\hline Labor_force $_{i t}$ & $\begin{array}{l}\text { Three-year averages (for period } t \text { to } t-3 \text { ) for proportion of the } \\
\text { population ages } 15 \text { or older that is economically active. }\end{array}$ & WDI \\
\hline Fertility $_{i t}$ & $\begin{array}{l}\text { Three-year averages (for period } t \text { to } t-3 \text { ) for number of } \\
\text { children that would be born to a woman if she were to live } \\
\text { to the end of her childbearing years and bear children in } \\
\text { accordance with age-specific fertility rates of the specified year. }\end{array}$ & WDI \\
\hline
\end{tabular}


End of Table A1

\begin{tabular}{|l|l|l|}
\hline \multicolumn{1}{|c|}{ Variable } & \multicolumn{1}{|c|}{ Brief description } & \multicolumn{1}{|c|}{ Source } \\
\hline$R \& D_{i t}$ & $\begin{array}{l}\text { Three-year averages (for period } t \text { to } t-3 \text { ) for gross domestic } \\
\text { expenditures on research and development (R\&D), expressed } \\
\text { as a percent of GDP, including both capital and current } \\
\text { expenditures in Business enterprise, Government, Higher } \\
\text { education and Private non-profits. }\end{array}$ & UNESCO \\
\hline Muslim $_{i}$ & $\begin{array}{l}\text { Dummy that identifies if the majority religion in the country is } \\
\text { Islam. }\end{array}$ & $\begin{array}{l}\text { International } \\
\text { Religious } \\
\text { Freedom Data }\end{array}$ \\
\hline Latin $_{i}$ & $\begin{array}{l}\text { Dummy that identifies the region Latin America if the country } \\
\text { belongs to that region. }\end{array}$ & By authors \\
\hline Landlocked $_{i}$ & $\begin{array}{l}\text { Dummy that identifies if the country has no direct access to a } \\
\text { coastline providing access to oceans. }\end{array}$ & By authors \\
\hline Crisis $_{t}$ & $\begin{array}{l}\text { Dummy that identifies the first year of the Great Recession, } \\
\text { 2008. }\end{array}$ & By authors \\
\hline
\end{tabular}

Note: †PWT: Penn World Tables (Feenstra et al., 2015); WDI: World Development Indicators (World Bank, 2018), FreeH: Freedom House, La Porta: La Porta et al. (1999), SIPRI: Stockholm International Peace Research Institute, and IRFD: International Religious Freedom Data.

Table A.2. List of Countries Analysed (source: By authors. ${ }^{\star}$ OECD countries)

\begin{tabular}{|c|c|c|c|c|}
\hline Albania (Alb) & Ecuador (Ecu) & Kazakhstan (Kaz) & Peru (Per) & Uganda (Uga) \\
\hline Algeria (Alg) & Egypt (Egy) & Kenya (Ken) & Philippines (Phi) & Ukraine (Ukr) \\
\hline Argentina (Arg) & El Salvador (Esa) & Kuwait (Kuw) & Poland $^{*}(\mathrm{Pol})$ & Un. Kingdom* (Gbr) \\
\hline Armenia (Arm) & Estonia $^{*}$ (Est) & \begin{tabular}{|l} 
Latvia (Lat) \\
\end{tabular} & Portugal $^{\star}$ (Por) & Un. States ${ }^{\star}$ (Usa) \\
\hline Australia* (Aus) & Ethiopia (Eth) & Lesotho (Les) & Rep. of Korea* (Kor) & Uruguay (Uru) \\
\hline Austria* (Aut) $^{*}$ & Finland* (Fin) & Lithuania (Ltu) & Rep. of Moldova (Mda) & Venezuela (Ven) \\
\hline Belgium* (Belg) & France $^{*}$ (Fra) & Luxembourg* (Lux) & Romania (Rou) & Viet Nam (Vie) \\
\hline Bolivia (Bol) & Gabon (Gab) & Madagascar (Mad) & Russian Fed. (Rus) & Zambia (Zam) \\
\hline Botswana (Bot) & Gambia (Gam) & Malaysia (Mas) & Saudi Arabia (Ksa) & \\
\hline Brazil (Bra) & Germany $^{\star}(\mathrm{Ger})$ & Mali (Mli) & Senegal (Sen) & \\
\hline Bulgaria (Bul) & Ghana (Gha) & Mauritius (Mri) & Singapore (Sin) & \\
\hline Burkina Faso (Bur) & Greece $^{\star}$ (Gre) & $\operatorname{Mexico}^{*}($ Mex $)$ & Slovakia $^{*}($ Svk $)$ & \\
\hline Burundi (Burnd) & Guatemala (Gua) & Morocco (Mar) & Slovenia* $^{*}$ (Slo) & \\
\hline Canada $^{*}$ (Can) & Honduras (Hon) & Mozambique (Moz) & South Africa (Rsa) & \\
\hline Chile $^{*}$ (Chi) & Hungary $^{\star}$ (Hun) & Nepal (Nep) & Spain $^{*}$ (Esp) & \\
\hline China (Chn) & India (Ind) & Netherlands* (Ned) & Sri Lanka (Sri) & \\
\hline Colombia $(\mathrm{Col})$ & Indonesia (Ina) & New Zealand ${ }^{*}(\mathrm{Nzl})$ & Sweden $^{\star}($ Swe $)$ & \\
\hline Costa Rica (Crc) & Iran (Isl. Rep.) (Iri) & Nicaragua (Nca) & Switzerland* (Sui) & \\
\hline Croatia (Cro) & Ireland $^{\star}($ Irl) & Nigeria (Ngr) & Thailand (Tha) & \\
\hline Cyprus (Сур) & Israel $^{\star}$ (Isr) & Norway $^{\star}$ (Nor) & Togo (Tog) & \\
\hline Czech Republic ${ }^{\star}$ (Cze) & Italy $^{*}$ (Ita) & Pakistan (Pak) & Tunisia (Tun) & \\
\hline D.R. of the Congo (Cod) & Jamaica (Jam) & Panama (Pan) & Turkey $^{*}$ (Tur) & \\
\hline Denmark $^{*}$ (Den) & Jordan (Jor) & Paraguay (Par) & U.R. of Tanzania (Tan) & \\
\hline
\end{tabular}


Table A.3. F-test provided for testing validity of instruments for endogenous covariates considered in BPMA (source: By author)

\begin{tabular}{|c|c|}
\hline Endogenous variable & F-test \\
\hline $\ln \left(y_{i 0}\right)$ & 0.000 \\
\hline$D_{i T-0}$ & 0.000 \\
\hline$P u b_{-} C_{i t}$ & 0.000 \\
\hline$\phi E_{i t}$ & 0.000 \\
\hline$R \& D_{i t}$ & 0.000 \\
\hline Fertility $_{i t}$ & 0.000 \\
\hline Mil_expit & 0.000 \\
\hline$U_{r b a n}$ & 0.000 \\
\hline Pop_dens $s_{i t}$ & 0.000 \\
\hline Labor_force $_{i t}$ & 0.000 \\
\hline Inflat $_{i t}$ & 0.000 \\
\hline $\ln \left(L_{i f e} e_{-} \exp e c t_{i t}\right)$ & 0.000 \\
\hline
\end{tabular}

Note: The instruments included are the five different lags and lagged differences available for the endogenous variable. 